\section{BRS Anauê and BRS Boyrá: the first cultivars of ornamental pineapple developed in Brazil}

\section{Fernanda Vidigal Duarte Souza ${ }^{1^{*}}$, Everton Hilo de Souza ${ }^{2}$, Janay Almeida dos Santos-Serejo ${ }^{1}$ and José Renato Santos Cabral ${ }^{1}$}

\begin{abstract}
BRS Anauê and BRS Boyrá are two ornamental pineapple cultivars bred for landscaping and cut flower and mini fruit production. They are characterized by intense colors, absence of spines, a long peduncle and high durability. In Brazil, they are the first pineapple cultivars officially released for commercial ornamental purposes.
\end{abstract}

Keywords: Ananas comosus (L.) Merrill, breeding, ornamental plant, landscaping, cut flowers, mini fruits.

\section{INTRODUCTION}

Ornamental pineapple [Ananas comosus (L.) Merrill] varieties, with their exotic features and colorful leaves and small fruits, are a novelty on the floriculture market. No official data of production and sale of ornamental pineapple plants and flowers in Brazil and worldwide are available. In Brazil, the production is concentrated in the Northeast region (Donato et al. 2018). Some varieties are already grown commercially in Brazil, such as $A$. comosus var. erectifolius and $A$. comosus var. bracteatus, mainly in the states of Ceará and Rio Grande do Norte, from where they are exported to the United States and European countries (Brainer and Oliveira 2007).

In the search for new ornamental cultivars since 2003, the Brazilian Agricultural Research Corporation (Embrapa) has conducted studies to characterize, select and hybridize the varieties preserved in a germplasm bank with more than 700 accessions (Souza et al. 2006, Souza et al. 2009a, Souza et al. 2012a, Souza et al. 2014). The development of new cultivars requires agronomic, phytosanitary and postharvest evaluations, to select hybrids with commercially important traits that are also resistant to the main crop pests and diseases (Souza et al. 2009a, Souza et al. 2014, Souza et al. 2019). The main commercial characteristics of ornamental pineapple, according to market standards, are a deformation-free peduncle (fruit-supporting stem), longer than $40 \mathrm{~cm}$, and attractive and wellformed infructescences (Souza et al. 2014, Lima et al. 2017).

The cultivars BRS Anauê and BRS Boyrá meet the beauty and quality requirements for floral stems required by the global market, as shown by surveys conducted at various international fairs (Donato et al. 2018). They can be used for landscaping and/or production of mini fruits and cut flowers. The production system for both cultivars was developed by Embrapa in partnership with the export company ABX Tropical Flowers, based in the state of Rio Grande do Norte. In addition, a system for organic production of BRS Anauê was developed
Crop Breeding and Applied Biotechnology 19:3, 382-386, 2019 Brazilian Society of Plant Breeding. Printed in Brazil http://dx.doi.org/10.1590/198470332019v19n3c54 \section{.}


in partnership with the rural elementary school Tina de Carvalho, supported by the Foundation José Carvalho, in the county of Entre Rios, Bahia.

The objective of this report is to present these two ornamental pineapple varieties to the scientific community and flower producers, by describing their characteristics and properties of novelty, homogeneity and genetic stability, according to the standards of the National Plant Variety Protection Service (SNPC) of Brazil.

\section{ORIGIN AND DEVELOPMENT OF THE CULTIVARS}

BRS Boyrá and BRS Anauê were developed on an experimental farm of the research unit Embrapa Cassava and Fruits (Embrapa Mandioca e Fruticultura) in Cruz das Almas, Bahia, from controlled crosses of two botanical varieties ( $A$. comosus var. bracteatus and A. comosus var. erectifolius) (Souza et al. 2014). Selection was based on the morphological descriptors developed for pineapple, published by the International Board for Plant Genetic Resources (IBPGR 1991). The genetic resources of a progeny represented by 1,207 spineless plants were used, because 4,923 plants with spines and other undesirable traits were excluded during preselection.

The characterization of these plants resulted in the selection of 64 promising varieties, categorized according to the intended main use, i.e., for landscaping, as potted plants, or for the production of cut flowers, cut foliage or ornamental mini fruits (Souza et al. 2014).

The seedlings for the agronomic validation tests were produced by micropropagation, as described by Souza et al. (2012b). The tests for resistance to fusariosis (Fusarium guttiforme Nirenberg \& O'Donnell) were carried out according to Souza et al. (2011). Among the selected varieties, BRS Anauê and BRS Boyrá stood out as having the quality attributes demanded by the cut flower and ornamental plant segment, aside from a good reproductive potential.

Thus, the two cultivars were evaluated in DHS (distinguishability, homogeneity and stability) tests, according to the SNPC requirements, and the agronomic value was confirmed by the company ABX Tropical Flowers, in the city of CearáMirim, Rio Grande do Norte, and at the rural school Tina de Carvalho/ Foundation José Carvalho, in Entre Rios, Bahia (Costa Junior et al. 2016). The evaluated aspects were based on a list of 30 quantitative and qualitative morphological descriptors developed for DHS testing by the Brazilian Ministry of Agriculture, Livestock and Supply (MAPA).

\section{PERFORMANCE}

The duration of the phenological stages between planting and flowering (Table 1) are fundamental for the planning and cultivation of ornamental pineapple cultivars.

Cultivar BRS Anauê has a medium height (between 54 and $67 \mathrm{~cm}$ ), semi-upright growth habit, short leaves (46 to 63 $\mathrm{cm}$ long), without anthocyanin variegation, greenish-yellow color, no spines, peduncle length of 37 to $45 \mathrm{~cm}$, reddish syncarp (compound fruit), two-colored crown (green on the edges and red in the center) and balanced crown/syncarp ratios (ratios close to 1 , for both length and diameter). The plant produces abundant tillers and is resistant to pineapple fusariosis.

Table 1. Duration of phenological stages (days) between planting and flowering of the cultivars BRS Anauê and BRS Boyrá after floral induction

\begin{tabular}{lcccc}
\hline \multirow{2}{*}{ Physiological stages } & \multicolumn{2}{c}{ BRS Anauê } & \multicolumn{2}{c}{ BRS Boyrá } \\
\cline { 2 - 5 } & 1st Cycle & 2nd Cycle & 1st Cycle & 2nd Cycle \\
\hline Induction/bud emergence & $29.35 \pm 1.14$ & $26.72 \pm 2.02$ & $40.80 \pm 3.08$ & $40.20 \pm 2.45$ \\
Induction/first flower & $51.65 \pm 2.76$ & $50.60 \pm 1.08$ & $51.16 \pm 0.42$ & $48.32 \pm 0.33$ \\
Planting/bud emergence & $469.38 \pm 1.12$ & $361.72 \pm 1.02$ & $480.80 \pm 3.05$ & $420.18 \pm 3.21$ \\
Bud emergence/last flower & $40.75 \pm 1.89$ & $40.40 \pm 2.12$ & $28.80 \pm 3.02$ & $27.30 \pm 2.40$ \\
First flower/last flower & $18.45 \pm 2.95$ & $16.52 \pm 1.42$ & $18.44 \pm 0.12$ & $18.19 \pm 0.63$ \\
Induction/last flower & $70.10 \pm 0.41$ & $67.12 \pm 2.54$ & $69.60 \pm 0.39$ & $68.97 \pm 0.45$ \\
Planting/last flower & $510.10 \pm 0.41$ & $402.12 \pm 1.54$ & $509.60 \pm 4.31$ & $447.48 \pm 4.32$ \\
\hline
\end{tabular}




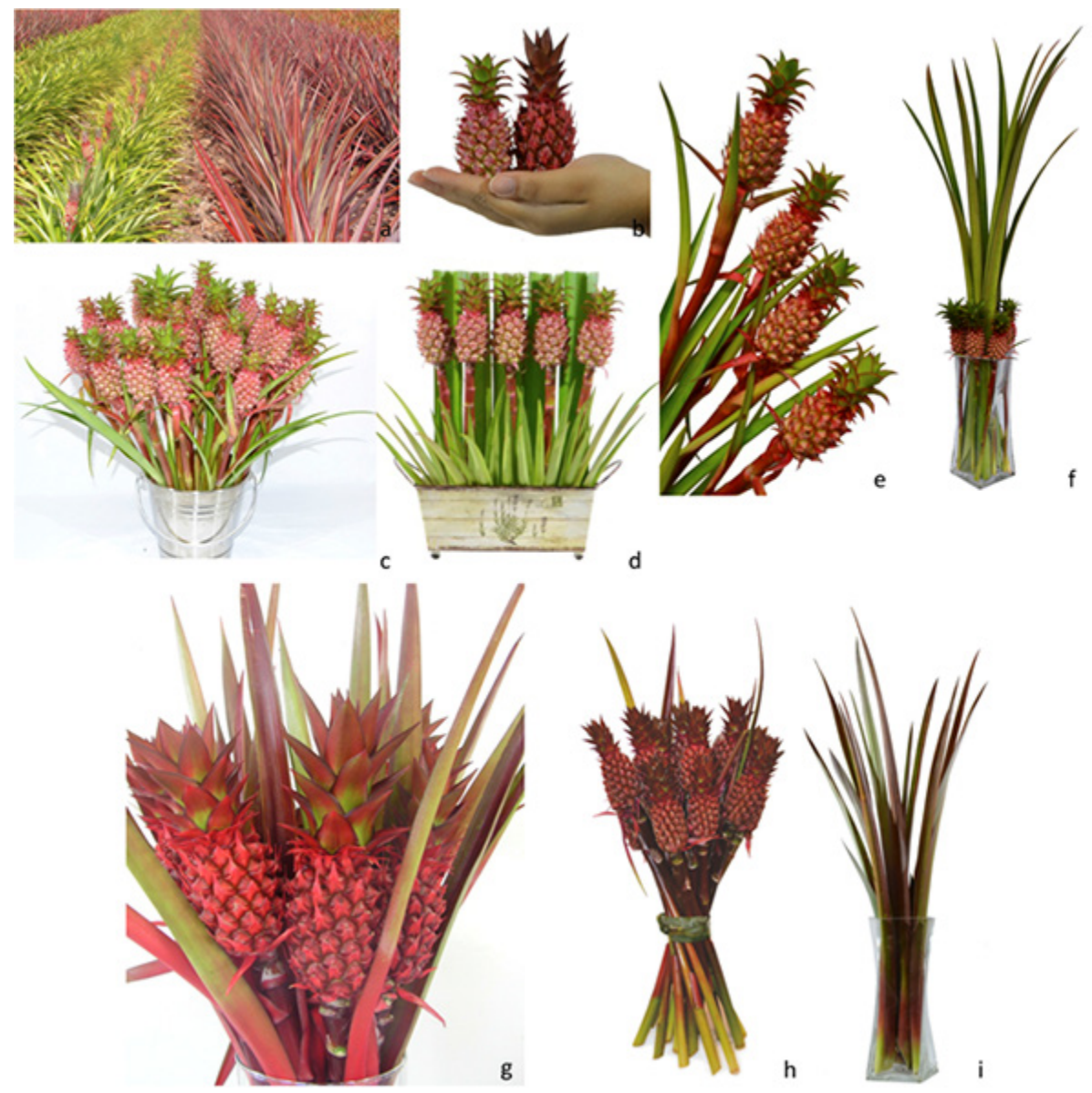

Figure 1. Ornamental pineapple cultivars BRS Anauê and BRS Boyrá developed by Embrapa Cassava and Tropical Fruits, Cruz das Almas, Bahia, Brazil. a) Cultivars BRS Anauê (left) and BRS Boyrá (right) in the field. b) Mini fruits of BRS Anauê (left) and BRS Boyrá (right). c-g) BRS Anauê in different forms and uses: cut flowers (c-e); cut foliage (f). (g-i) BRS Boyrá in different forms and uses: cut flowers (g-h) and cut foliage (i).

On the other hand, BRS Boyrá has a high stature $(>72 \mathrm{~cm})$, upright growth habit, long leaves $(>71 \mathrm{~cm})$, purplish-gray to green leaves, no spines, a peduncle longer than $36 \mathrm{~cm}$, syncarp, reddish-gray crown and balanced crown/syncarp ratios. The plant also produces abundant tillers, but is moderately susceptible to pineapple fusariosis.

The main product of commercial interest of both cultivars is the floral cut stem. Each plant produces one floral stem per cultivation cycle, so the yield corresponds to the number of plants grown per hectare. BRS Anauê can be planted at a density of 80,000 plants ha-1 and BRS Boyrá at 70,000 plants ha-1.

These two cultivars differ from those currently available on the market, especially in terms of leaf, syncarp and crown colors. Both cultivars are mainly intended for cut flower production, but are also excellent for landscaping, as potted plants or for ornamental mini fruit production (Figure 1). The main characteristics of the two cultivars were evaluated in two production cycles (Tables 2 and 3 ).

The recommendations for crop management of the two cultivars are described in the Embrapa Document Series 169, entitled "Produção de abacaxizeiro ornamental para flor de corte" (available only in Portuguese - "Production of ornamental pineapple plants as cut flower"). The recommended postharvest treatment is to wash the peduncle and crown to remove trichomes, without affecting the syncarp. After this washing, the stem color and quality appear more clearly. The post-harvest durability of the stem is good ( 15 days). 
BRS Anauê and BRS Boyrá: the first cultivars of ornamental pineapple developed in Brazil

Table 2. Quantitative morphological traits of the cultivars BRS Anauê and BRS Boyrá

\begin{tabular}{|c|c|c|c|c|}
\hline \multirow{2}{*}{ Variables } & \multicolumn{2}{|c|}{ BRS Anauê } & \multicolumn{2}{|c|}{ BRS Boyrá } \\
\hline & 1st Cycle & 2nd Cycle & 1st Cycle & 2nd Cycle \\
\hline Plant height $(\mathrm{cm})$ & $60.75 \pm 6.44$ & $62.65 \pm 5.09$ & $87.11 \pm 14.22$ & $93.84 \pm 7.49$ \\
\hline Leaf length $(\mathrm{cm})$ & $53.10 \pm 6.50$ & $59.10 \pm 4.58$ & $80.99 \pm 9.61$ & $79.54 \pm 6.28$ \\
\hline Leaf width (cm) & $3.57 \pm 0.20$ & $3.58 \pm 0.39$ & $3.99 \pm 0.67$ & $4.72 \pm 0.32$ \\
\hline Peduncle length (cm) & $40.20 \pm 2.87$ & $42.00 \pm 3.41$ & $40.45 \pm 4.11$ & $46.28 \pm 5.33$ \\
\hline Peduncle diameter $(\mathrm{cm})$ & $0.90 \pm 0.10$ & $0.91 \pm 0.08$ & $1.25 \pm 0.13$ & $1.62 \pm 0.17$ \\
\hline Crown length $(\mathrm{cm})$ & $3.39 \pm 0.51$ & $3.14 \pm 0.45$ & $4.27 \pm 0.55$ & $5.07 \pm 0.60$ \\
\hline Crown diameter $(\mathrm{cm})$ & $3.56 \pm 0.47$ & $3.79 \pm 0.38$ & $3.83 \pm 0.27$ & $4.40 \pm 0.48$ \\
\hline
\end{tabular}

Table 3. Quantitative morphological traits of the cultivars BRS Anauê and BRS Boyrá

\begin{tabular}{|c|c|c|}
\hline Descriptors $^{1}$ & BRS Anauê & BRS Boyrá \\
\hline Growth habit & Semi-upright & Upright \\
\hline Leaf variegation & Absent & Present \\
\hline Distribution of variegation & - & Marginal \\
\hline Main color of the upper leaf surface & Greenish-yellow & Purplish-gray \\
\hline Leaf anthocyanin pigmentation & Absent & Present \\
\hline Spines on leaves & Absent & Absent \\
\hline External color of syncarp skin & Red & Reddish-gray \\
\hline Syncarp shape & Cylindrical & Cylindrical \\
\hline Fruitlet bract tip shape & Sharp & Sharp \\
\hline Bract overlap over fruitlets & Total & Total \\
\hline Color of fruitlet bracts & Red & Reddish-gray \\
\hline Crown/syncarp length ratio & Low & Low \\
\hline Crown/syncarp diameter ratio & Low & Low \\
\hline Number of crown colors & Two & One \\
\hline Shape of crown leaf tip & Moderately sharp & Very sharp \\
\hline Fusariosis reaction & Resistant & Mod. susceptible \\
\hline
\end{tabular}

Descriptors used in distinguishability, homogeneity and stability (DHS) tests of cultivars, according to the Brazilian Ministry of Agriculture, Livestock and Supply (MAPA).

\section{SEED PRODUCTION}

Both cultivars were registered (no. 35771 -BRS Anauê and no. 35772 -BRS Boyrá) by the Brazilian Ministry of Agriculture, Livestock and Supply, and with intellectual property protection numbers 20170217 (BRS Anauê) and 20170218 (BRS Boyrá). The parent plants of both cultivars are maintained in a greenhouse and also in vitro, under the responsibility of Embrapa Cassava and Fruits. The Secretariat of Innovation and Business of Embrapa (Secretaria de Inovação e Negócios da Embrapa) produces licensed seed of both cultivars.

\section{ACKNOWLEDGMENTS}

The authors wish to thank the Empresa Brasileira de Pesquisa Agropecuária (Embrapa), the Research Foundation of the State of Bahia (FAPESB), the National Council for Scientific and Technological Development (CNPq 304269/2018-2), the Brazilian Federal Agency for Support and Evaluation of Graduate Education (CAPES/Embrapa/2014, CAPES/PNPD 88882.315208/2019-01), Tina Carvalho Rural Elementary School/ José Carvalho Foundation and ABX Tropical Flowers for the financial and technical support of the project. 


\section{REFERENCES}

Brainer MSCP and Oliveira AAP (2007) Floricultura: perfil da atividade no Nordeste Brasileiro. Banco do Nordeste, Fortaleza, 351p.

Costa Junior DS, Souza EH, Costa MAPC, Pereira MEC and Souza FVD (2016) Clonal evaluation of new ornamental pineapple hybrids to use as cut flowers. Acta Scientiarum. Agronomy 38: 1-12.

Donato GN, Souza EH, Souza JS and Souza FVD (2018) Public perception and acceptance of ornamental pineapple hybrids. Ornamental Horticulture 24: 116-124.

IBPGR - International Board for Plant Genetic Resources (1991) Descriptors for pineapple. IBPGR, Roma, 41p.

Lima OS, Souza EH, Dias LEC, Souza CPF and Souza FVD (2017) Characterization and selection of ornamental pineapple hybrids with emphasis on sinuous stems and black fruits1. Pesquisa Agropecuária Tropical 47: 237-245.

Souza EH, Costa MAPC, Santos-Serejo JA and Souza FVD (2014) Selection and use recommendation in hybrids of ornamental pineapple. Revista Ciência Agronômica 45: 409-416.

Souza EH, Matos AP, Souza FVD, Costa Junior DS, Trocoli RO and Costa MAPC (2011) Evaluation of ornamental pineapple hybrids for resistance to Fusarium subglutinans f. sp. ananas. Acta Horticulturae 902: 381-386.
Souza EH, Souza FVD, Carvalho MJS, Souza AS and Carvalho MAP (2012b) Growth regulators and physical state of culture media in the micropropagation of ornamental pineapple hybrids. Plant Cell Culture \& Micropropagation 8: 1-12.

Souza EH, Souza FVD, Costa MAPC, Costa Júnior DS, Santos-Serejo JA, Amorim EP and Ledo CAS (2012a) Genetic variation of the Ananas genus with ornamental potential. Genetic Resources and Crop Evolution 59: 1357-1376.

Souza FVD, Cabral JRS, Cardoso JL and Benjamin DA (2006) Identification and selection of ornamental pineapple plants. Acta Horticulturae 702: 93-99.

Souza FVD, Cabral JRS, Souza EH, Ferreira FR, Nepomuceno OS and Silva MJ (2009a) Evaluation of $\mathrm{F}_{1}$ hybrids between Ananas comosus var. ananassoides and Ananas comosusvar. erectifolius. Acta Horticulturae 822: 79-84.

Souza EH, Rosa SS, Souza FVD and Melo VC (2009b) Indução floral em Neoregelia carolinae (Beer) L. B. Sm e Aechmea fasciata (Lindley) Baker, (Bromeliaceae). Magistra 21: 305-310.

Souza TLPO, Pereira HS, Peloso MJD, Faria LC, Costa JGC, Wendland A, Díaz JLC, Magaldi MCS, Aguiar MS, Carvalho HWL, Souza Filho BF, Melo CLP, Costa AF, Almeida VM, Posse SCP and Melo LC (2019) BRS FP403: high-yielding black-seeded common bean cultivar with superior grain quality and moderate resistance to fusarium wilt. Crop Breeding and Applied Biotechnology 19: 240-244. 